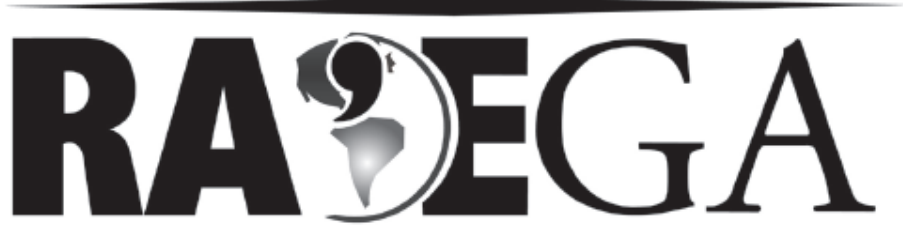

O ESPAÇO GEOGRÁFICO EM ANÁLISE

\title{
METODOLOGIAS DE PESQUISA PARA O ESTUDO GEOGRÁFICO DA SOCIABILIDADE JUVENIL
}

\section{METHODOLOGY OF RESEARCH TO THE STUDY ON YOUTHFUL SOCIABILITY}

\author{
Nécio TURRA NETO ${ }^{1}$
}

\begin{abstract}
RESUMO
Nossa intenção é apresentar as metodologias de pesquisa acionadas na concretização dos objetivos da tese, sobre os diversos tempos e espaços da sociabilidade juvenil. Tratam-se de metodologias de cunho qualitativo, não de todo desconhecidas dos estudos geográficos, mas, apesar disso, pouco refletidas. São elas: observação participante, História Oral e entrevistas e "grupos de debate". Com esta reflexão, espero contribuir com geógrafas e geógrafos iniciantes, que procuram referências metodológicas para suas pesquisas, bem como com o debate sobre a dimensão metodológica nos estudos geográficos.
\end{abstract}

Palavras-Chave: Observação Participante; História Oral; Memória; Entrevistas; Grupos de Debate.

\section{ABSTRACT}

This study aims to present the methodologies of research used to carry out the dissertation requirements related to the different times and spaces linked to the youth sociability. The methodologies are about qualitative features not at all unknown to the geography studies despite the little account taken on them. The methodologies are: eyewitness accounts, Oral History, interviews and "groups of debate". With this purpose, this work intends to bring some contribution to geographers and beginners that have been looking for methodological references to their researches it also tries to facilitate the discussion on the methodological dimension in the geographical studies.

Keywords: Eye-Witness Accounts; Oral History; Memory; Interviews; Groups of Debate.

\footnotetext{
${ }^{1}$ Doutor em Geografia pela FCT/UNESP - Campus de Presidente Prudente. Professor do Departamento de Geografia da FCT/UNESP, membro do GASPERR.
} 


\section{INTRODUÇÃO}

A proposição deste artigo surge do desejo de dar maior visibilidade, a um dos debates que desenvolvi na tese de doutorado, concluída no Programa de Pós-Graduação em Geografia da UNESP - Presidente Prudente ${ }^{2}$, qual seja, sua reflexão metodológica; pois entendo que o tema das metodologias de pesquisa em Geografia precisa ser mais e melhor desenvolvido.

Como a metodologia não parte do nada, mas da necessidade de resolver um problema de pesquisa. Inicio, então por este.

A tese teve como objetivos principais: 1. estudar as trajetórias juvenis constituídas ao longo do tempo, na cidade de Guarapuava, articuladas às transformações nos espaços e práticas de sociabilidade, até chegar ao período atual; 2. realizar um mergulho no presente, para estudar os grupos de sociabilidade juvenil, que se constituem em torno das culturas punk e hip-hop, entendidas como referências transterritoriais, que encontraram condições de territorialização na cidade. A pergunta norteadora, inspirada em Haesbaert (2004), era a seguinte: o que foi necessário se desterritorializar para que a nova territorialização acontecesse; como se caracteriza essa nova territorialização?

Para atingir o primeiro dos objetivos, foi necessário buscar informações quanto às vivências juvenis de gerações passadas ${ }^{3}$. Para o segundo objetivo, era preciso entender como as culturas juvenis punk e hip-hop chegaram a Guarapuava, como constituíram-se em referência para a formação de redes de sociabilidade e, sobretudo, de que forma se territorializaram e se territorializam hoje, na cidade.

A partir desses delineamentos, busquei estratégias metodológicas para a produção daquelas informações, que permitiriam construir respostas satisfatórias para as questões e, assim, atingir os objetivos propostos. Foram acionadas, então, as metodologias da História Oral e entrevistas; observação participante; e "grupos de debate". Tratam-se de metodologias de cunho qualitativo, que se prestam muito bem ao trabalho de desvendamento da cultura, das quais resultaram uma pluralidade de "documentos orais" (MEIHY, 2002) e uma "descrição densa" (GEERTZ, 1978) - bases sobre as quais a tese foi construída.

\footnotetext{
${ }^{2}$ A tese intitula-se "Múltiplas Trajetórias Juvenis em Guarapuava: territórios e redes de sociabilidade", concluída em setembro de 2008.

${ }^{3} \mathrm{Na}$ tese, foram pesquisadas as gerações que viveram sua juventude na cidade de Guarapuava nas décadas de 1950 e 1970 .
} 
O debate sobre metodologias de pesquisa se faz necessário por dois aspectos: pelo fato de haver uma carência na disciplina geográfica da reflexão sobre metodologias próprias de pesquisa, o que obriga aos geógrafos e geógrafas a recorrerem a outros campos disciplinares; por ser a partir das metodologias, que as informações, sobre as quais o trabalho se edifica, são produzidas e/ou coletadas, de modo que elas interferem diretamente, sobre os próprios resultados finais da pesquisa.

Nesse sentido, espero que 0 artigo contribua com as pesquisadoras e pesquisadores iniciantes, que também valorizam a dimensão metodológica em seus estudos e estão em busca de referências, bem como com o debate sobre essa dimensão no campo da Geografia brasileira, pela apresentação de uma experiência concreta de pesquisa.

Como já foi dito, a preocupação, no campo da Geografia brasileira, com metodologias apropriadas à compreensão das lógicas das "manifestações da cultura no espaço" não parece ser muito significativa. As metodologias propostas para a pesquisa vem, portanto, de outros campos do conhecimento, como a Antropologia, a História, a Sociologia e a Educação que, há mais tempo que a Geografia, tem seu foco de estudo nos sujeitos sociais.

Primeiramente, é preciso considerar que, ao lidar com metodologias de outras disciplinas, é necessário ter o cuidado de não cometer reducionismos, desconsiderando o quadro teórico em que elas foram desenvolvidas. Em cada um dos campos do saber há uma discussão de longa data sobre as metodologias aqui em foco; há debates de tendências divergentes e há novas propostas em cena. Entrar nessas searas, vindo de outro campo é, certamente, um desafio. Percorrer o caminho dessas metodologias nas ciências que a desenvolveram é outro desafio, mas indispensável para quem deseja "se apropriar" delas.

Na sequencia, apresentarei uma reflexão epistemológica inicial, que se pergunta sobre as possibilidades do conhecimento (reflexão que antecede o debate metodológico e o fundamenta). Depois, apresento cada uma das metodologias, buscando, sempre que possível, articular o referencial teórico com relatos da forma como elas foram efetivamente apropriadas. Por fim, faço uma reflexão sobre o trabalho de sistematização escrita, que se segue à pesquisa empírica, visto que estas metodologias produzem uma enormidade de informações qualitativas, que são de difícil mensuração. 


\section{ALGUNS PRESSUPOSTOS PARA INÍCIO DE CONVERSA}

Antes da discussão sobre as metodologias qualitativas da observação participante, História Oral e entrevistas e "grupos de debate", é importante refletir, preliminarmente, sobre as possibilidades do conhecimento, questão epistemológica básica, de cuja resposta emergirão diferentes concepções de ciência e de procedimentos metodológicos, por isso, ela é o ponto de partida.

Quando me propus a pensar as metodologias da pesquisa, a questão que norteou a reflexão foi: qual a melhor maneira de buscar informações que respondam à problemática construída no âmbito do projeto? Essa questão inicial conduziu, inevitavelmente, à outra, mais profunda: seria possível conhecer a verdade dos fatos ou, simplesmente, construiríamos interpretações em relação a eles, sempre limitadas e parciais e, conseqüentemente, contestáveis?

$\mathrm{Na}$ impossibilidade de não tomar uma posição diante dessas questões, minha tendência tem sido concordar com Silva, T. (2003, p. 12), quando argumenta que "a existência de um objeto [de pesquisa] é inseparável da trama lingüística que o descreve". Ou seja, aquilo que o discurso científico diz sobre determinado aspecto da realidade está envolvido no processo de produção dessa própria realidade, não só enquanto tal, mas também como objeto científico. De modo que, seria um equívoco pensar que as teorias científicas e os conceitos derivados "descobrem" o real e que a realidade assim "descoberta" é uma entidade independente do sujeito que a descreveu.

Isso posto, é possível dizer que os discursos que construímos sobre as coisas do mundo não desvendam de uma vez por todas o real, lançando sobre ele um foco de luz, que o faz mostrar-se tal como é. Nesses termos, tenho argumentado que, os discursos que produzimos não são definitivos, mas tão somente aqueles que ganharam condições de emergência no percurso da pesquisa. São mais contingentes e parciais do que pensava certa concepção de ciência, que buscava a objetividade científica.

Portanto, a forma como a pesquisa de campo é realizada indica e influencia os dados disponíveis e a forma da escrita. Então, o que se tem como resultado de uma pesquisa é fruto de um processo contingente e contextualizado de investigação, no qual são determinantes as opções do/a pesquisador/a. Os resultados seriam outros, se outras fossem as opções e os caminhos metodológicos percorridos.

Em síntese, nessa perspectiva, os discursos que a pesquisa constrói sobre a realidade são os discursos possíveis e seus limites são dados pelas formas de conduzir a 
pesquisa, que permitiram a emergência de certas informações e não de outras. É por isso que, os "caminhos investigativos" devem ser conscientemente construídos e claramente explicitados no texto. Assim, o leitor e a leitora podem fazer seu próprio julgamento e concordar ou não com o que foi escrito. Como o autor, reconhecendo essas limitações, já não tem pretensões de ascender a conclusões definitivas, pois sabe da impossibilidade de produzi-las, o/a leitor/a é chamado/a a participar do processo de interpretação, construindo suas próprias conclusões. Para isso, é preciso que o relato final da pesquisa seja elaborado de modo que o leitor/a possa acompanhar o desenrolar de sua trajetória e a estruturação de suas conclusões. O que se coloca em questão aqui é a própria autoridade do autor, que abre mão da última palavra, em prol de um diálogo aberto com a leitora e o leitor.

Também está em jogo a autoridade da teoria, que é tida como uma das possibilidades interpretativas, não a única ou mais verdadeira. Como se verá, ao longo do artigo, essa postura não significa um relativismo sem fim, nem um desprezo à teoria, mas uma mudança de postura em relação a ela. O que se evidencia é uma postura mais modesta, que reconhece seus limites, sua subjetividade e problematiza o papel da teoria no processo de construção da pesquisa, sobretudo da pesquisa em detalhe, da abordagem microscópica, que é a escala privilegiada pelas metodologias aqui em foco.

Na verdade, a opção metodológica não se dissocia da teoria, sendo que a primazia é sempre da primeira. A metodologia, na verdade, é "teoria materializada", que apreende a realidade empírica tal como ela é construída no quadro de relações teóricas. Em outros termos, as dimensões operacionais nada mais são do que o modo como o conceito teórico se concretiza na realidade empírica (MARRE, 1991). Contudo, na pesquisa qualitativa, a teoria pode e deve ser reconstruída no processo de interpretação da realidade particular e não engessar a capacidade imaginativa do pesquisador. Sendo o ponto de partida, a teoria não é a palavra final. Ela pode ser até o ponto de chegada da trajetória da pesquisa, mas, provavelmente, sairá transformada do processo, visto que o que se privilegia nesse tipo de pesquisa é o diálogo, em que a realidade (contingencialmente levantada pelas metodologias qualitativas) tem sempre um peso maior e, talvez, ela sim possa dar a última palavra.

Este prelúdio é necessário para indicar a importância que a reflexão metodológica adquire na pesquisa contemporânea, sobretudo, daquela que se coloca o desafio da autoreflexividade, ou seja, de pensar-se enquanto se faz e saber-se limitada. 
As metodologias que serão apresentadas a seguir não são de todo estranhas ao trabalho geográfico, que há muito desenvolve as estratégias de observação e de entrevistas na condução das pesquisas. O que falta, contudo, é uma reflexão mais aprofundada sobre elas, como forma, inclusive, de constituir uma auto-reflexão sobre nossos próprios processos de produção e coleta de informações.

Inicio, então, pela discussão sobre a História Oral, no trabalho com a memória, e a técnica da entrevista que the é correlata. Apresento em seguida a observação participante, que é a metodologia com a qual tenho maior familiaridade. Em seguida, apresento o que estou chamando de "grupos de debate", que é, dentre as metodologias aqui expostas, aquela mais desconhecida na Geografia.

\section{HISTÓRIA ORAL E ENTREVISTAS: A ESCUTA DA MEMÓRIA.}

História Oral e entrevistas são metodologias relacionadas na produção de documentos orais, fontes importantes de dados para pesquisas de processos históricos e de representações sociais. A primeira é mais geral e fornece os subsídios para pensar o que são estas fontes e qual o significado que elas podem assumir num trabalho acadêmico. As entrevistas, por sua vez, são mais especificamente as técnicas pelas quais se tem acesso à memória, matéria-prima da História Oral.

Inicio, então, pelo mais geral. Para tanto, minha base principal está no texto de Meihy (2002), que se propôs a construir um "Manual de História Oral". Para este autor, a História Oral subverte o saber disciplinar, na medida em que seus adeptos são de várias disciplinas, como a Geografia Humana, a Antropologia, a Sociologia e mesmo a História.

Ela própria tem uma história que, para Meihy, inicia-se na década de 1940, nos Estados Unidos. Posteriormente, ela foi retomada pela nova esquerda britânica, assumida como uma forma de "contra história" ou "outra história", estudando os "silenciados", os excluídos, com importantes implicações ideológicas. Mas, foi somente com a onda da contracultura, dos anos de 1960, que a História Oral se internacionalizou, ganhando o mundo ainda com esse enfoque mais político.

Para Cohen (1993), justamente na década de 1960, houve um retorno à subjetividade, como tema de pesquisa, nas Ciências Sociais, fato que, aliado aos novos movimentos sociais do período, fizeram da História Oral um novo paradigma, voltado para o estudo dos marginalizados. Difundiu-se assim, como uma história militante. Sua 
principal justificativa era a possibilidade de produzir uma documentação alternativa à oficial e de escutar os "excluídos da história" (DEBERT, 1986). Contudo, com o passar do tempo, esse impulso inicial se arrefeceu e a busca em "revelar o oprimido", deu lugar à busca do contato com uma pluralidade de experiências sociais. Assim, a História Oral deixou de ser um paradigma alternativo e passou a ser equiparada a outras metodologias qualitativas de pesquisa (COHEN, 1993).

Há vários tipos de História Oral, das quais destaco, por conta dos limites do artigo, a História Oral de Vida e a História Oral Temática. A primeira é muito mais subjetiva que objetiva, sua força, aliás, reside nisso. É a "narrativa do conjunto da experiência de vida de uma pessoa". O/a colaborador/a, ou informante, tem liberdade total para dissertar sobre sua trajetória. Ele/a escolhe todo o jeito de narrar. Nesse tipo de História Oral, a intervenção do investigador é mínima. Deve deixar a fala fluir espontaneamente, pois as lembranças e os esquecimentos fazem parte do material para ser analisado (MEIHY, 2002).

A História Oral Temática é mais objetiva. Para Meihy (2002, p. 145), ela

[...] é a que mais se aproxima das soluções comuns e tradicionais de apresentação dos trabalhos analíticos em diferentes áreas do conhecimento acadêmico. [...]

A história oral temática é quase sempre usada como técnica, pois freqüentemente articula diálogos com outros documentos.

Valendo-se do produto da entrevista como se fosse mais um documento, compatível com a necessidade de busca de esclarecimentos, o grau de atuação do entrevistador como o condutor dos trabalhos fica muito mais explícito. Mesmo assim, seria equivocado considerar o colaborador um informante no sentido superado do termo.

Mesmo estabelecendo estas distinções, o autor reconhece que há projetos temáticos que combinam também História de Vida. E este parece ser o caso da pesquisa que desenvolvi, visto que, ao perguntar pela vida das pessoas, queria saber, com mais ênfase, do período de sua juventude. Nesse sentido, trabalho com algo de História de Vida, mas ela é também Temática porque o interesse direciona o diálogo, que gira em torno de questões sobre grupos juvenis, espaços e práticas de sociabilidade e sobre a estrutura urbana do período da juventude da pessoa.

$\mathrm{Na}$ verdade, é pela trajetória de vida das pessoas que tive acesso às formas de realização da juventude nos períodos estudados (gerações de 1950 e 1970). No caso das entrevistas com os integrantes das culturas juvenis punk e hip-hop, também foram articuladas a História Oral Temática e a História Oral de Vida. Interessava-me pela 
trajetória da infância à juventude, o momento em que se descobriu a cultura da qual passou a fazer parte, como foi conhecendo as pessoas que formaram seu grupo de referência, além de explorar relatos opinativos sobre a situação contemporânea do movimento na cidade.

Ainda no campo das definições de História Oral, Meihy aconselha que se explicite a forma como ela será encarada na pesquisa: se como técnica, como recurso de referência, como método ou como disciplina independente.

Para os que tratam a História Oral como mero recurso, os documentos orais não diferem muito de outras fontes, ou de outras abordagens da mesma temática. Nesse caso, os depoimentos são simples detalhes que complementam a pesquisa.

No outro extremo, estão os mais radicais, que propõem a História Oral como um novo caminho, uma disciplina do futuro. Nesse sentido, buscam fixá-la e fundamentá-la em termos epistemológicos.

Como método, que é o tratamento que mais nos interessa aqui, os depoimentos são privilegiados como o foco central dos estudos. Nesse sentido, argumenta Meihy (2002, p. 44),

Trata-se de focalizar as entrevistas como ponto central das análises. Para localizálas metodologicamente, os oralistas centram sua atenção, desde o estabelecimento do projeto, nos critérios de recolhimento das entrevistas, em seu processamento, na passagem do oral para o escrito e nos resultados.

Para serem garantidas como método, as entrevistas precisam ser ressaltadas como o nervo da pesquisa. Os resultados devem se efetivados com base nelas.

Essa opção metodológica - de ter nas entrevistas o foco principal da análise deve ser considerada à luz da reflexão sobre a memória, individual e coletiva, à qual o trabalho com História Oral inevitavelmente conduz e que não é sem importância para o resultado final da pesquisa.

É consenso entre os/as autores/as estudados/as, que a memória não é um fenômeno exclusivamente individual, mas resulta de "determinações sociais complexas" (HALL, 1992), por isso, a história oral é sempre social (MEIHY, 2002). Para Queiroz (1991), a História de Vida, por mais individual e subjetiva que possa ser, tem interesse justamente porque, por meio dela, se pode ter acesso ao grupo, captar algo que ultrapassa o próprio indivíduo narrador.

Contudo, é preciso considerar que, ainda que a memória individual seja influenciada pela coletiva, portanto, semelhante à de outras pessoas, ela é sempre única 
e original (AMADO, 1995). Por isso, cada entrevista, cada relato, tem um valor em si mesmo, que não the pode ser subtraído. A arte de narrar o passado é profundamente pessoal, ainda que o que se narra esteja vinculado a uma construção coletiva, no sentido de que algumas identidades assumidas e/ou impostas ao indivíduo funcionam como importantes filtros sobre a narrativa. Dentre essas, as que exercem mais forte influência são: classe social, gênero e etnia (MEIHY, 2002). Nesse sentido, a conclusão óbvia é que o trabalho da memória sobre os fatos passados não os apresenta tal como ocorreram, mas são já, desde sempre, uma interpretação.

Hall (1992), expondo os "riscos da inocência" em História Oral, argumentou que as fontes orais devem ser submetidas ao mesmo trabalho crítico que os historiadores realizam com outras fontes, pois é preciso reconhecer que a narrativa não reflete a experiência direta dos informantes, mas sim o trabalho que a memória fez sobre ela. E a recordação, no mais das vezes, está sujeita a alterações, tanto pelas experiências posteriores dos sujeitos, como pela transferência de opiniões atuais para o passado. Por isso, a História Oral nunca pode ser plenamente confiável.

Em outro sentido, Amado (1995) também reconhece esses "limites" do trabalho com História Oral. A autora argumenta que é preciso distinguir entre o vivido e a memória. Enquanto o primeiro remete a uma experiência concreta, a segunda recria o passado. "Das lembranças brota uma outra história". Assim, em toda memória há uma "dose de ficção", seu papel é criativo, não reflexivo. E isso não é necessariamente um limite, sobretudo, quando se reconhece que a busca da verdade não é propriamente um objetivo da pesquisa com História de Vida (QUEIROZ, 1991) e Temática.

Para Meihy (2002), em História Oral, não existe mentira no sentido literal do termo. O documento oral não tem pretensão de ser fonte de verdade, mas é uma interpretação dos fatos, uma reconstrução a partir do presente, em que lembrança e imaginação jogam um papel importante. Mentiras, esquecimentos, deformações fazem parte de qualquer narrativa do passado, por isso, o documento oral não pode ser usado como referência objetiva.

Não importa perguntar se os relatos são verdadeiros, o que importa é que não se poderá mais pensar sobre os fatos pesquisados sem se lembrar deles. "[...] estamos lidando com o fictio - no sentido especificado por Geertz, de algo construído ou modelado e não de falsidade" (DEBERT, 1986, p. 156).

A consideração de que os documentos orais - aqui não só os produzidos pela memória, mas também aqueles produzidos por relatos de opiniões sobre fatos e 
acontecimentos presentes, que estão se processando - não têm obrigação de serem verdadeiros, tem implicações profundas na forma como eles devem ser incorporados e encarados dentro da pesquisa. Talvez, também aqui, esteja reforçando o argumento da perda da autoridade da teoria que se constrói numa pesquisa desse tipo, que tem nos documentos orais a principal fonte de sua constituição. Esta pesquisa lidaria, portanto, com informações nas quais não se pode confiar cegamente, visto que passaram pelo filtro da memória e da imaginação.

Assim, ao lado da observação participante, como se verá adiante, a História Oral contribui para fazer da pesquisa realizada, um trabalho em que se impõe uma despreocupação com a objetividade de fatos, datas, localizações. Uma pesquisa em que as considerações devem ser relativizadas, como decorrentes do encontro entre subjetividades, do autor e dos/as informantes, e na qual o ensaio é a forma mais indicada de construí-la como uma ficção, como desenvolverei no último item do artigo.

Além disso, é preciso reconhecer que o pesquisador e pesquisadora participam ativamente da construção das narrativas orais dos sujeitos, na situação de entrevista, o que tem reflexos na qualidade das próprias narrativas. Para Macioti (1988), para fugir das fontes de erros, normalmente atribuídas à História Oral, como por exemplo, a relação entrevistador $\leftrightarrow$ entrevistado e a confiança exacerbada na transparência do material oral, é preciso, por um lado, reconhecer que dados perfeitos não existem e, por outro, dar atenção às condições de realização das entrevistas. Nesse sentido, Queiroz (1991) recomenda que as entrevistas sejam acompanhadas de uma ficha de identificação do/a entrevistado/a e de um diário de campo, no qual se descrevem as condições da entrevista, que se torna também uma variável na sua posterior análise, pois reconhece que a situação da entrevista tem impactos sobre a qualidade da narrativa.

As entrevistas ${ }^{4}$ são um meio de captar informação e, como tal, devem estar sempre sobre "controle metodológico", ou seja, o pesquisador deve refletir constantemente sobre seus pressupostos teóricos e suas fontes de distorção. Trata-se de uma técnica de relacionamento, de comunicação entre investigador e investigado/a (THIOLLENT, 1980). Uma comunicação controlada por um problema de pesquisa, pois, por mais livre que ela seja, é sempre o pesquisador que está no comando da atividade. A

\footnotetext{
${ }^{4}$ Queiroz (1991) reconhece a existência de três tipos principais de entrevistas: 1 - rigorosamente centrada nas perguntas do pesquisador; 2 - entrevista com um simples roteiro, semi-orientada; 3 - entrevista realmente livre. Em cada uma delas, varia o grau de intervenção do/a entrevistador/a, os dados que podem emergir e o papel do/a informante. A opção, por qual tipo de entrevista aplicar, deve ser orientada pelos objetivos da pesquisa. No caso particular da minha pesquisa, trabalhei a partir da entrevista semi-orientada, que seguia um roteiro simples, a partir do qual muitas outras perguntas eram desdobradas no decorrer do diálogo com o/a entrevistado/a.
} 
entrevista supõe uma conversação continuada e dirigida. A captação dos dados decorre da maior ou menor capacidade do pesquisador de orientar o/a informante a discorrer sobre o tema, e isso acaba sendo um fator de perturbação para o/a informante (QUEIROZ, 1991), sempre submetido a uma "imposição da problemática" (THIOLLENT, 1980), que marca a relação social da entrevista.

Para Thiollent (1980), mesmo as entrevistas semi-diretivas não conseguem fugir da imposição da problemática, que consiste em colocar o/a entrevistado/a diante de problemas que Ihe são estranhos, ou que the são formulados por outro. Esta imposição pode produzir "respostas reativas", que visam justamente escapar de uma situação embaraçosa.

Aliado a isso, há a distância social entre os dois pólos do diálogo, que também pode provocar respostas distorcidas. Para Thiollent, estes problemas são muito difíceis de serem contornados, mas a reflexividade sobre sua existência, bem como certa dose de relativismo cultural, podem ajudar a construir o "bom senso" que é, em última análise, o fator que determina a qualidade do trabalho.

Há certo consenso de que a responsabilidade pela transcrição da fita gravada é do pesquisador coordenador do projeto que, supõe-se, seja o mesmo que realizou a entrevista. Nesse ponto, há um debate sobre se a transcrição deve ser literal ou pode haver alguma tradução. Meihy defende que a entrevista deve ser corrigida, mantendo-se o sentido original dado pelo narrador. É esse texto trabalhado que deve vir a público. Mas essa é mais uma opção da pesquisa que, claro, deve ser explicitada ao leitor ${ }^{5}$.

Uma última questão a abordar é relativa ao "formulário de consentimento informado" que, segundo Bogdan e Biklen (1994), faz parte dos procedimentos éticos da pesquisa com informantes. Trata-se de um documento que informa a natureza da pesquisa e solicita autorização do/a entrevistado/a para uso da sua entrevista. Esse termo deve ser lido e devidamente assinado pelo pesquisador e pelo/a entrevistado/a. Alguns exemplos de formulários podem ser encontrados no livro de Meihy (2002). No Anexo 1, apresento o formulário elaborado para minha pesquisa em particular, que foi assinado por todos os entrevistados e entrevistadas.

\footnotetext{
${ }^{5}$ No caso específico da minha pesquisa, houve uma pequena revisão, que limpou as falas dos excessos de "né", "então", "assim", pausas e erros de concordância muito gritantes, mas não chegou a ser uma revisão tal como aquela recomendada por Meihy (2002) que, depois de feita, deve ser enviada ao entrevistado ou entrevistada, para que se obtenha seu aval, atestando que não houve nenhuma distorção de sua fala.
} 
Como já foi dito, a História Oral (de Vida e Temática) foi empregada não apenas com pessoas de outras gerações (que viveram sua juventude em Guarapuava nas décadas de 1950 e 1970), mas também com membros dos grupos juvenis punk e hip-hop.

No caso da entrevista com jovens, os roteiros foram construídos a partir das observações de campo e procuraram aprofundar informações, confirmar ou refutar hipóteses e abrir para novas questões, ainda não consideradas. Iniciavam-se por questões relativas à história de vida, ao processo de descoberta das referências culturais punk e hip-hop e ao processo de ajuntamento em redes de sociabilidade, depois, seguiam-se as questões formuladas a partir das observações de campo.

Os roteiros de entrevistas com pessoas de outras gerações basearam-se em informações disponíveis sobre a história das juventudes em geral e sobre a história urbana de Guarapuava. Iniciavam-se pela trajetória da família da pessoa, seguiam pela infância e a passagem para a juventude e focalizavam, por fim, os espaços, práticas e referências para a constituição dos grupos de sociabilidade, em cada período.

As pessoas da geração de 1950, na época da pesquisa, por volta dos seus 70 anos de idade, foram contatadas a partir de grupos da "Melhor Idade", que se reúnem periodicamente em igrejas, SESC etc. Chegava às reuniões desses grupos, apresentavame como professor da Universidade e falava da pesquisa. Dizia que precisava de colaboradores para dar entrevistas, mas que estes deveriam ter vivido sua juventude na cidade de Guarapuava. Saía das reuniões com uma lista de nomes, que depois eram contatados e as entrevistas marcadas. Às vezes, deparava-me com a situação da pessoa ter mais idade do que o esperado e vivido sua juventude não nos anos de 1950, mas no ano de 1940, ou mesmo em 1930. Nesses casos, continuava a entrevista normalmente. Ao final da pesquisa, essas entrevistas de jovens antes de 1950 me deram a dimensão de algumas transformações que se processariam para a juventude de 1950, ou seja, mesmo que não tenha sido planejada ou buscada, a informação acabou por ser muito valiosa.

Nesses casos, bem como nos casos das pessoas que viveram sua juventude nos anos de 1970, o primeiro contato se dava justamente no momento da entrevista. A situação inicial de constrangimento, principalmente diante do gravador, era inevitável. Alguns permaneceram tensos a maior parte do tempo, respondendo com frases curtas todas as perguntas. Outros engajavam-se num bate-papo descontraído, o que resultou em ótimos depoimentos. 
Ao final das entrevistas, sempre pedia para que fizessem uma comparação com a geração de seus filhos e netos. No geral, essa comparação chamou a atenção para a liberalização dos costumes.

A geração de 1970 foi acessada a partir de uma rede de conhecidos. Nesse caso, a comparação inter-geracional foi bastante esclarecedora, pois os filhos dessa geração eram os/as jovens contemporâneos à pesquisa, ainda que não engajados em culturas juvenis como a punk e hip-hop. Foi através, portanto, da geração de 1970 que pude ter acesso à condição juvenil, mais geral, da primeira década do século XXI, de Guarapuava.

As entrevistas com as gerações de 1950 e 70 foram empregadas para reconstruir a cidade de cada período e as referências culturais e espaciais das práticas de sociabilidade. Reconstruíram também certa atmosfera na qual se desenrolavam essas práticas, onde se davam os namoros e se formavam os grupos de amizade.

Com os jovens das culturas punk e hip-hop, a situação de entrevista já era bem mais descontraída. Partia de uma relação anterior, construída na vivência de campo, pela observação participante, e se caracterizava muito mais por uma conversa do que por um esquema de perguntas e respostas. Na verdade, algumas dessas entrevistas, dado o nosso conhecimento mútuo, nossa confiança e entrosamento anterior, configuraram-se como uma troca de impressões sobre o movimento punk ou hip-hop. Além disso, foram momentos importantes para conhecer a trajetória de vida dos/as jovens estudados.

A partir delas foi possível acompanhar, pormenorizadamente, a tessitura das redes de sociabilidade em torno das culturas juvenis e os vários modos de vinculação a elas. As entrevistas com jovens também me permitiram coletar opiniões sobre a vivência na cultura juvenil e sobre os diálogos e dilemas que cada uma proporciona e produz, reforçando ou retificando as observações de campo.

\section{OBSERVAÇÃO PARTICIPANTE: POSSIBILIDADES E LIMITES.}

A observação participante é uma velha conhecida. Tenho me apropriado dela na quase totalidade das minhas pesquisas com grupos juvenis. Foi a partir dela que pude, mais diretamente, ter acesso aos territórios punk e hip-hop.

Para partir de uma definição, tomo um dos conceitos de observação participante, pelo qual tenho me orientado: 
[...] um processo pelo qual mantém-se a presença do observador numa situação social com a finalidade de realizar uma investigação científica. O observador está em relação face-a-face com os observados e, ao participar da vida deles, no seu cenário natural, colhe dados. Assim, o observador é parte do contexto sob observação, ao mesmo tempo modificando e sendo modificado por este contexto (SCHUARTZ \& SCHUARTZ, apud CICOUREL, 1980, p. 89).

Como se percebe, trata-se de uma metodologia que requer um envolvimento do pesquisador com o grupo a ser estudado. Uma convivência demorada, uma participação na vida das pessoas, que transforma tanto o grupo, quanto o pesquisador. Um processo de desvendamento mútuo que, depois, é transposto ao texto etnográfico como resultados da pesquisa.

Para Winkin (1998, p. 132), a etnografia que, de forma bastante simplificada, tomo aqui como sinônimo de observação participante, tornou-se, ao mesmo tempo, uma arte e uma disciplina científica, que consiste em saber ver, saber estar - com os outros e consigo mesmo - e, por fim, em saber escrever. "Arte de ver, arte de ser, arte de escrever. São estas as três competências que a etnografia convoca".

É preciso mencionar, que esta metodologia não oferece um conjunto de regras fixas, ou um guia de percurso para o pesquisador em campo. O que se apresenta, nos autores e autoras que a discutem, são sugestões, a partir de experiências já realizadas, relatos de como cada um/a foi se deparando com problemas no campo e os resolvendo. Por isso, observação participante, como afirma Becker (1999), é um tipo de metodologia que exige certo grau de improvisação. Nesse sentido, concordo com Diógenes (1998) quando afirma que há alguns indícios dos caminhos a serem seguidos, alguns sinais, mas é no caminhar que cada um constrói seu próprio trajeto, que é único, porque cada realidade estudada é única e apresentará seus próprios problemas, que demandarão soluções originais.

Por isso, Becker (1999, p. 12) propõe um "modelo artesanal de ciência", no qual cada um/a deve ser livre, para construir as teorias e metodologias mais apropriadas a suas pesquisas. Com isso, o autor não quer dizer que devemos ignorar os princípios gerais e as teorias estabelecidas por outros/as, mas que podemos e devemos desenvolver nossas próprias teorizações, adaptando, por vezes e quando necessário, e submetendo sempre, os princípios gerais às situações específicas.

Na proposta da observação participante, o modelo de interação do pesquisador no campo é o modelo dialógico. O pesquisador não tem, sobre o outro, o "nativo", uma posição privilegiada na produção de um dado conhecimento; ambos são equiparados 
(LACERDA, 2003) e compartilham "condições de modernidade", bem como experiências cotidianas sobre as quais é possível dialogar (MARCUS, 1991).

Lacerda (2003, p. 9) vê nessa relação uma tensão fundamental, não entre os sujeitos, mas entre a teoria e a realidade. Nas suas palavras, uma tensão

[...] entre o saber acumulado na disciplina e as categorias nativas apresentadas pelos informantes, [que] impactam na personalidade total do etnógrafo, fazendo com que diferentes culturas se comuniquem na experiência singular de uma única pessoa [...] Desse modo, a descoberta antropológica já é um diálogo, mas não entre indivíduos - pesquisador e nativo -, e sim entre teoria acumulada e o confronto com uma realidade que traz novos desafios para ser compreendida.

Transito aqui pelo campo do que se tem chamado "antropologias pós-modernas", ou "etnografias experimentais" (como prefere Lacerda), que realizou uma relativização da Antropologia Clássica, em que "o nativo" era submetido a uma "autoridade soberana" do/a pesquisador/a. Todavia, Lacerda chama a atenção para uma outra tensão, agora entre pontos de vista distintos dentro da disciplina, ou seja, a esta tendência Pós-Moderna, contrapõe-se outra que recusa abandonar a teoria, aquele lado mais sistematizante, científico e generalizante da Antropologia.

Acredito, contudo, que a proposta dialógica não seja uma recusa da teoria, mas a sua relativização, em contato e em diálogo com os sujeitos no campo de estudos - e não um monólogo do sujeito do conhecimento sobre o objeto, legitimado pelo status da ciência, como sinônimo de único saber rigoroso e válido. Na perspectiva defendida aqui, a teoria passa a ser encarada como mais um discurso entre outros. Ao recusar este "saberpoder", o investigador reconhece suas limitações e coloca suas conclusões como apenas mais uma, dentre as várias possibilidades interpretativas do fenômeno estudado. É, por isso, que o/a leitor/a é chamado/a para também participar do diálogo etnográfico e construir suas próprias conclusões, já que não existem interpretações definitivas. Para isso, o texto deve lhe garantir (ao/a leitor/a) os subsídios necessários, de modo que a própria leitura seja, em si mesma, uma atividade de pesquisa.

Novamente, o que está em causa aqui é tanto a autoridade do autor, quanto o papel da teoria na pesquisa, seja aquela que a antecede e fundamenta, seja aquela que se constrói a partir dela.

É importante reforçar que, ao campo, não se vai destituído de teoria, como se se tratasse uma vivência qualquer, sob pena da pesquisa cair num espontaneismo exacerbado. A leitura antecede o campo e oferece os modelos iniciais dos sujeitos com 
os quais o/a pesquisador/a irá dialogar. O que se deve evitar, a todo custo, é que esses modelos teóricos sejam amarras demasiado fortes, que aprisionem o pensamento, tapem os ouvidos e que tornem os/as pesquisadores/as cegos/as para a emergência de questões ainda não consideradas. Pelo contrário, estas imagens devem ser subvertidas pelo que, no campo, aparece como específico. De outro modo, do que serviria sair a campo, a partir da observação participante, se não fosse justamente para escutar o que naquele contexto há de novo, há de possibilidade para relativização teórica e para construção de novas teorias? E são, nessas teorias (re)construídas, que a pesquisa, apresentando os detalhes das informações que as fundamentam, coloca-se como abertura ao diálogo com o leitor e a leitora.

Não tenho aqui a intenção de esgotar esse debate, que é bastante polêmico no campo da própria Antropologia, e não quero parecer demasiadamente intrometido ao expô-lo de forma tão superficial, vindo de outro campo disciplinar. A intenção é apresentar questões que certamente emergem no trabalho com a observação participante, pois, na medida em que se propõe um mergulho em profundidade num contexto cultural bastante específico e realizar uma "descrição densa" (GEERTZ, 1978), o debate sobre o papel da teoria é certamente inevitável. Talvez seja, por isso, que estas "etnografias experimentais" sejam chamadas também de "auto-reflexivas", pois acabam por colocar em questão sua própria autoridade.

Nesse sentido, o "modelo artesanal de ciência" de Becker torna-se, realmente, uma ideia síntese do que até agora foi exposto. Por isso, é difícil, e mesmo indesejável, que se faça um tratado de metodologia científica, dissociado de uma pesquisa concreta, na qual a metodologia tenha sido testada, pois significaria dissociá-la do seu processo mesmo de realização. É o que tentarei apresentar agora.

O que mais me encanta nos autores e autoras, que trabalham a partir da observação participante, é, sobretudo, o reconhecimento da importância da interação humana, a despreocupação com a atitude estritamente científica no campo, a abertura à entrada da emoção e dos sentimentos.

A primeira questão que aparece, diz respeito ao processo de entrada e aceitação no grupo que se quer pesquisar. Boa parte dos/as autores/as lidos fala de um processo de negociação da pesquisa. As pessoas com as quais o pesquisador irá trabalhar sabem que não são obrigadas a colaborar com um trabalho científico e, por isso, o pesquisador deve demonstrar que não representa nenhum perigo ao grupo, e que está disposto, inclusive, a colaborar e a participar de suas atividades. 
Sobre isso, Foote-Whyte (1980) afirma que a aceitação do pesquisador no grupo depende mais da pessoa que ele revela ser aos olhos dos outros, do que dos fundamentos lógicos da sua pesquisa. Assim, a relação pessoal é a dimensão mais relevante para a aceitação no grupo. Nesse sentido, vão também as argumentações de Cicourel (1980) e Becker (1999) sobre o assunto.

Ainda sobre esse início, sempre difícil, de entrada no grupo a ser estudado, Winkin (1998) dá dicas importantes: 1 - não ver nada relevante logo de início, não significa que a pesquisa será um fracasso, é preciso ter paciência e esforçar-se na construção de laços interpessoais; 2 - os constrangimentos iniciais são inevitáveis e certamente serão superados pela conquista da familiaridade; 3 - as entrevistas devem ser realizadas num momento posterior e não no início do contato. A observação vem sempre em primeiro lugar. É preferível ter uma perspectiva própria do grupo, do lugar, onde a pesquisa se realiza, do que conseguir logo de saída chaves interpretativas daqueles/as que os conhecem bem. A observação deve ser, inclusive, a fonte a partir da qual se constroem as entrevistas.

Essa primeira fase da pesquisa é decisiva - o estabelecimento dos contatos e a conquista da confiança das pessoas, a permissão e aceitação da convivência -, pois indicam como serão os contatos posteriores. Por isso, uma boa porta de entrada no grupo é fundamental - como, por exemplo, uma pessoa em quem o grupo confia e respeita.

O exercício da observação participante, bem como das demais metodologias empregadas neste artigo, permite uma aproximação com o argumento de Ibañez (1989, p. 75) que, a partir de outro contexto de discussão, dá uma ideia preciosa da atitude necessária na investigação qualitativa: a "atitude de escuta", que "[...] expressa a máxima abertura possível do sujeito da investigação" àquilo que, no campo, há de novidade, de específico, que ainda não foi visto ou pensado, que pode surpreender e relativizar a teoria.

Vários outros autores dão respaldo para esta atitude de abertura para o inusitado do campo. Da Matta (1978), por exemplo, fala que se deixar levar pelo contato sensível pode ser, mesmo, o melhor caminho. Nesse sentido, não há como planejar o contato, a aproximação, a convivência, que se dão no fluxo da vida dos sujeitos. No campo, emergem sentimentos, emoções e sensações que podem causar estranhamento, mas que fazem parte de qualquer interação humana e, como na observação participante a interação humana é condição para sua realização, a subjetividade do pesquisador e a troca intersubjetiva tem um peso enorme na vivência e, inclusive, na análise. E isso é 
tanto mais assustador, quanto maior for a preocupação com a objetividade científica. Assim, na observação participante, reconhece-se o peso da subjetividade, tanto no registro, quanto na posterior interpretação da informação.

Todavia, é preciso reconhecer, também, tal como o fez Cicourel (1980), que na observação participante, corre-se o risco de adotar o ponto de vista do grupo e tornar-se cego para questões relevantes cientificamente. Um risco que é tanto maior, quanto maior o grau de participação no grupo. O autor também argumenta que, na participação intensiva, há o problema do intervalo de tempo entre a observação e o seu registro. Assim, trata-se sempre de uma "observação retrospectiva", na qual o pesquisador recria, na sua imaginação, toda a cena, os diálogos e seus sentimentos, além de tentar colocarse no lugar das pessoas, que participaram daquela cena e decifrar seus sentimentos, registrando tudo isso no diário de campo - importante instrumento nesse tipo de pesquisa, que é preciso reforçar.

Winkin (1998) atribui três funções principais ao diário de campo: 1 - função catártica, emotiva, pela qual o pesquisador deposita seus pensamentos e sentimentos mais íntimos sobre sua experiência no campo, sua relação com as pessoas, suas visões sobre elas etc., o que explica a necessidade do diário ser algo privado; 2 - função empírica, pela qual se anota tudo, mesmo aquilo que parecer insignificante; 3 - função reflexiva e analítica, na qual o diário se constitui fonte de consulta. É possível dizer que, o diário de campo talvez seja a principal fonte de informação da pesquisa, que se apóia na observação participante. Por isso, deve ser levado com muita seriedade e toda participação, nos mínimos detalhes, rigorosamente relatada no diário.

Winkin ainda sugere que, a cada releitura do diário de campo, as observações sejam anotadas com cores diferentes, para se construir "estratos" de interpretação, sendo esses, desde então, parte do processo de elaboração escrita da pesquisa.

O diário de campo permite que informações consideradas irrelevantes, num primeiro momento, possam se tornar chaves interpretativas da pesquisa, a partir de sua contextualização na totalidade dos relatos, dimensão que só se atinge quando o campo chega ao fim.

Para exemplificar, tomo como referência minha própria experiência no universo punk de Londrina ${ }^{6}$. A pesquisa produziu mais de 90 páginas digitadas, base para a construção do texto final. Acompanhando o fluxo da vida dos punks londrinenses, sempre,

\footnotetext{
${ }^{6}$ Trata-se da dissertação de mestrado desenvolvida também na FCT/UNESP - Presidente Prudente. Confira Turra Neto (2004).
} 
em conversas informais, as informações apareciam espontaneamente. Qualquer coisa podia desencadear narrativas. Às vezes, apenas tempos depois, percebia que o que foi falado em tal dia era um dado importante, o que só foi possível devido ao registro detalhado das informações no diário de campo.

O diário é, assim, o instrumento que reflete o processo de aproximação com o grupo estudado, bem como o deciframento mútuo, pela consideração de como as questões que se tornaram relevantes foram aparecendo e sendo respondidas. A totalidade da vivência é dada pela sua releitura, ao final da pesquisa, também numa "atitude de escuta", mas, sobretudo, de seleção das informações que podem ajudar na interpretação do grupo estudado.

Como já foi dito, esta metodologia também foi empregada no estudo das culturas punk e hip-hop de Guarapuava, no âmbito das quais convivi cerca de quatro meses (em cada uma). Pela observação participante, pude ter ideia da dinâmica socioespacial na cidade, dos territórios, bem como dos conflitos, que caracterizam ambas as culturas juvenis. Com a observação participante, então, tive acesso à particularidade do acontecer localizado dessas culturas transterritoriais na cidade. Os resultados aparecem descritos detalhadamente na tese, seguindo a forma da "história natural das conclusões" (BECKER, 1999), que aprofundarei mais adiante.

As questões que buscava desvendar em cada um dos grupos giravam em torno da sua territorialidade, da experiência da cidade que constituíam, a partir da cultura juvenil e das relações que estabeleciam com outros sujeitos sociais e grupos juvenis. Acredito que essas questões não poderiam ser simplesmente respondidas a partir de metodologias como questionários, ou mesmo entrevistas individuais. Era preciso experimentar a cidade e a territorialização dos jovens.

Assim, busquei inicialmente contatos, primeiro com o universo punk de Guarapuava. Alguns e-mails, seguidos de encontros, para conversas e explicações sobre a pesquisa, com um membro do grupo, garantiram-me um passaporte para a cena punk. A partir desse informante inicial, que reconheceu a relevância da pesquisa e aceitou contribuir, tive acesso aos eventos, que aconteciam na cidade, e a outros integrantes, com os quais ampliava a rede de contatos no grupo. O envolvimento, os tempos e espaços da pesquisa, a freqüência dos contatos, tudo dependia da dinâmica da própria cena local, de modo que foram, também, dados importantes para o desvendamento do universo punk em Guarapuava. 
Inevitavelmente, alguns dos contatos se tornaram mais estreitos que outros e poderia mesmo dizer que, dois deles ultrapassaram o nível do contato entre pesquisador e investigado, para o nível da camaradagem e da amizade. Esses, ao mesmo tempo em que se tornavam bons amigos, eram, também, os principais informantes da pesquisa. Com eles, além das conversas freqüentes, havia as saídas pela cidade, os encontros em festas e shows. Com eles por perto, atenuava-se a sensação de estrangeiro nos shows punk e nas rodas de conversa pelo calçadão, no centro da cidade. Foi a partir deles, então, que a rede de contatos da pesquisa foi costurada. Isso indica que o universo punk de Guarapuava é mais amplo do que aquele que conheci no campo, pelas próprias limitações que a interação humana nos coloca. A empatia não se deu de forma homogênea com todos os/as jovens que aderiram à cultura punk na cidade. Alguns/as foram mais abertos, que outros, ao diálogo com o pesquisador que, no campo, às vezes, confundia-se com o grupo, mas que, inevitavelmente era sempre alguém mais velho - um professor universitário, que estava ali para pesquisar a cena punk. Certa vez escrevi em meu diário de campo:

Apesar de todo o esforço, percebo ainda certo constrangimento no ar com a minha presença em algumas rodas. São, na maior parte, pessoas muito jovens, com dezesseis/dezessete anos. O que parece é que para as garotas da Formol [banda musical ativa na cena, durante o período da pesquisa], o punk é, em grande medida, uma forma de diversão, de curtir som, beber, beijar e, ao mesmo tempo, construir um visual e relações distintivas, dentro de um cenário juvenil marcado pelo predomínio de referências pop da cultura de massa.

Minha presença parecia inibir essa diversão autêntica, pois o punk também tem outro lado mais politizado e racional. Penso que a presença de uma pessoa pesquisando o punk impunha a eles e elas a necessidade de racionalizar discursos e comportamentos, pois estavam sob observação, o que era pesado demais para quem só queria diversão. $E$ o punk tem uma dimensão de diversão que não se pode negar, sem a qual, como diria M., "o negócio fica chato". A própria cultura punk surge como uma forma de articular uma diversão autêntica, criando espaços específicos, fora dos circuitos de diversão juvenil mais tradicionais.

O contato com o universo punk, pela observação participante, permitiu-me concluir que estava num cenário que não tinha nada de homogêneo, apesar das pessoas dizerem compartilhar o mesmo referente cultural. Permitiu-me observar que a vivência do punk é 
variável conforme a origem socioespacial do sujeito, sua idade e as relações que estabelece no meio. Uma diversidade que é objeto de conflitos internos, que contribuem, por sua vez, para a fragilização do que poderia representar a emergência de um sujeito político no lugar, pela constituição de um movimento social juvenil. Para ilustrar, segue outra anotação do diário de campo, em que comento uma conversa com um dos meus principais informantes, que me permitiu iluminar melhor esta questão:

[...] ele me relatava alguns eventos interessantes dos quais não pude participar, envolvido que estava em outras atividades acadêmicas. Um que marcou, foi a discussão entre ele e uma das integrantes da banda Formol (não as duas que fazem o fanzine, um terceira). Ele disse não suportá-la, pois ela se define punk, mas tem umas "idéias muito fracas", que não condizem com a visão informada de mundo que têm os punks. Essa garota, na sua opinião, só quer beber e curtir som, bebe inclusive coca-cola e diz que é o melhor refrigerante do mundo. Numa atitude evidente de provocação em relação aos punks mais ortodoxos.

Disso, é possível pensar, como o mesmo referente punk é vivido e incorporado de formas distintas no lugar. $O$ que é causa de conflitos. $O R$. é um punk que procura ser fiel a certos princípios do movimento. Enquanto essa garota usa este referente, mas não se informa sobre os sentidos mais profundos e políticos da identidade, ficando na superfície da diversão. A diferença de idade entre eles pode também jogar um papel nessas rixas. O R. é mais velho e mais antigo no punk, já faz Faculdade de História, a garota ainda está no Ensino Médio e descobriu o punk recentemente, quando começou a sair de casa para divertir-se sem o ostensivo controle dos pais.

Contudo, ambos pertencem à mesma cena e, ainda que não façam parte da mesma turma, têm muitos amigos em comum. Isso faz pensar que o jogo de proximidades e distanciamentos é muito mais complexo do que, normalmente, aparece problematizado nos estudos: os mesmos referentes aproximam, mas os usos e sentidos e as formas como cada qual os vivencia provocam novas proximidades e distanciamentos. É preciso considerar também que cada um faz suas próprias mesclas entre o referente punk $e$ outros referentes, que marcaram suas histórias de vida, que fazem sentido ainda hoje e dos quais não querem se desvencilhar.

Em síntese: a partir dos relatos do R., é possível afirmar que, compartilhar os mesmos referentes culturais transterritoriais não significa necessariamente construir identidade/amizade entre as pessoas e, certamente, isso joga um papel importante nos modos do acontecer e da territorialização do punk no lugar. 
Assim, paralelamente, a vivência no punk guarapuavano, conhecendo seus conflitos, permitiu-me, também, caracterizar a territorialidade que se efetiva na relação desses jovens com a cidade, a partir da identidade cultural eleita. Acompanhando trajetórias, permanências, negociações por espaço, pude ver que a dinâmica do movimento se reflete na forma de territorialização e que esta tem um papel indiscutível na forma como o movimento acontece no lugar, o que aponta para a existência de uma inequívoca dialética entre território e cena punk, que diz muito sobre a trajetória localizada da cultura global.

Terminada a pesquisa com o movimento punk, pelo ponto final que havia me proposto a dar, tendo em vista o cronograma da pesquisa, iniciei o trabalho com o movimento hip-hop. Neste, o campo foi realizado com dois grupos de rap, que se tornaram o centro da observação participante. $O$ contato com esses grupos se deu por intermédio de um velho conhecido do movimento, respeitado na cidade, por ter um programa de rádio em que divulga o rap. Em ambos os grupos, foi marcado encontro nos seus respectivos bairros, em sábados à noite, cada um a seu tempo. Em comum tiveram o fato de que o grupo, a princípio, queria saber do que se tratava a pesquisa, qual sua intenção, ao que respondia objetivamente: a intenção é conhecer o modo de vida dos jovens que são do movimento hip-hop.

Cada um dos grupos, então, quis apresentar o "discurso oficial", falar da ideologia do movimento, apresentar seu som, enfim, dar aquilo que acreditavam que tinha ido buscar. Contudo, aos pouco foram percebendo que aquele não seria o único encontro, que eu estaria mais vezes no bairro, que nos encontraríamos também no centro, que faríamos juntos os trajetos bairro-centro e de volta ao bairro, enfim, que conviveríamos nos tempos-espaços em que isso fosse possível. Foi então que pude ter acesso a algo mais do que aquilo que, discursivamente, eles estavam dispostos a me mostrar. A confiança foi se construindo gradativamente e fui também fazendo parte do grupo, superando certo estranhamento inicial e passando a ter maior familiaridade com aqueles jovens, seus comportamentos e, sobretudo, com suas formas de ser e estar na cidade, a partir de sua posição socioespacial, enquanto jovens moradores da periferia pobre.

Foi graças a esse envolvimento (que não classificaria como intenso), que pude vislumbrar as angústias desses jovens na sua vivência da cidade. As carências de todos os tipos que os acompanham, na sua trajetória de vida e os esforços que realizam para viverem uma juventude possível, a partir dos referentes que a cultura hip-hop thes oferece. Esforços em estar juntos, em comprar música e visual, em estar no centro da 
cidade, entre jovens que também são da cultura, são realizados em meio a trajetórias escolares irregulares, marcadas por fracasso e deserção, bem como por relações intermitentes e degradantes de trabalho. O hip-hop lhes oferece uma forma mais autônoma de construção de si, num contexto de ausência quase absoluta de sentido, e, ao mesmo tempo de territorialização mais autônoma na cidade, ultrapassando os limites dos espaços segregados, como diria Diógenes (1998).

Assim, tanto na cultura punk, quanto na hip-hop, a observação participante possibilitou atualizar o mapeamento da territorialização das redes de sociabilidade juvenis na cidade - que seria complementada com a trajetória histórica de ambas as culturas, acessada pela memória desses jovens. Identifiquei territórios que não são fixos, mas que se realizam no movimento (casa-rua, bairro-centro), que são efêmeros, indissociáveis dos encontros, que articulam a rede de sociabilidade, também formando um território em rede, como diria Haesbaert (2004). Tal territorialidade dificilmente seria verbalizada por meio de entrevistas formais, só podendo ser decifrada acompanhando a vivência dos sujeitos que se territorializam, daí a relevância dessa opção metodológica.

\section{GRUPOS DE DISCUSSÃO E GRUPOS FOCAIS.}

Situo minha aproximação dessas metodologias no campo da experimentação, de forma que é preciso reconhecer que cometi certa confusão entre ambas - grupos de discussão e grupos focais. Apesar de terem origem similar, diferenciam-se quanto aos procedimentos operacionais básicos. Para contornar essa confusão, prefiro aqui não fazer opção entre uma ou outra, por isso, emprego o termo "grupo de debate", que buscou produzir um documento oral a partir da interação dos jovens que fazem parte da cultura juvenil.

Para Cruz Neto; Moreira e Sucena (2002), a técnica dos grupos focais é um importante instrumento para o futuro das Ciências Sociais. Ganhou maior evidência nos anos de 1980 e, desde então, tem conquistado cada vez mais adeptos. Seu impulso maior vem das pesquisas de mercado. Nas Ciências Sociais entrou pela porta da política, com pesquisas do perfil dos eleitores, espalhando-se posteriormente para outros setores da pesquisa social.

Quanto aos grupos de discussão, Meinerz (2005) argumenta que, desde a década de 1960, já era uma prática consolidada nas pesquisas de mercado, constituindo-se 
alternativa à abstração das enquetes estatísticas de pesquisa de opinião. O que evidencia uma origem similar aos grupos focais. Nas Ciências Sociais, esta é uma prática qualitativa surgida na chamada "Escola de Qualitativismo de Madrid".

Os grupos focais podem ser definidos como uma técnica de pesquisa em que se reúnem pessoas para coletar dados, a partir do diálogo e do debate entre elas sobre um tema específico. O objetivo também é produzir uma "fala em debate" (CRUZ NETO; MOREIRA e SUCENA, 2002). Não se trata de entrevista de grupo, pois objetiva a interação do grupo para gerar dados. Os/as participantes são encorajados/as a falar uns com os outros, a se perguntarem, a trocarem experiências (ROSA, 2004) e não a interagir com o pesquisador, que apenas tem papel de mediador do debate.

A definição de grupos de discussão assemelha-se muito a esta. As distinções, se entendi bem, estão, sobretudo, no papel desempenhado pelo mediador ou preceptor do grupo. No grupo focal, não há restrição quanto ao fato do mediador conhecer as pessoas selecionadas para o grupo, desde que tenha uma reflexão sobre a influência desse conhecimento prévio nas respostas produzidas. O mediador intervém mais, recomendase, inclusive que ele disponha de um roteiro de debate, com certo número de questões e com tempo restrito a cada uma delas. Não há preocupação com consensos, desde que todos/as expressem sua opinião sobre a questão em pauta de forma eqüitativa. $\mathrm{O}$ grupo pode ser reunido mais de uma vez, em torno de questões diferentes (CRUZ, MOREIRA e SUCENA, 2002; ROSA, 2004).

Quanto ao grupo de discussão, as restrições são maiores. O preceptor, como é nomeado a pessoa que medeia a discussão, nesse caso, não participa do debate com novas questões, não introduz novas informações, apenas trabalha sobre as informações produzidas no grupo, reformulando-as ou interpretando-as e as lançando, novamente, na roda para aprofundamento, mas apenas quando essa intervenção for necessária, para não deixar o debate cair num longo silêncio. Ao final, seria desejável que o grupo chegasse a um consenso sobre o tema, introduzido no começo. A atitude do preceptor é de escuta, sem expressar julgamentos sobre o que dizem. Entre ele e os membros do grupo, não deve haver contato prévio, bem como dos membros do grupo entre si. Em função disso, o processo de seleção dos membros deve ser realizado por uma outra pessoa. O grupo não se reúne novamente. A opção é que se organizem outros grupos em torno das mesmas temáticas (MEINERZ, 2005; IBAÑEZ, 1989; ORTí, 1989). Para Ibañez, o grupo deve surgir do nada e ao nada retornar. Termina quando chega ao consenso. No grupo de discussão, não interessa o grupo em si, mas sim o "agrupamento artificial", 
construído com objetivos específicos e que depois se dissolve. Trata-se de uma "situação pública" de encontro entre pessoas que não se conhecem. Cada participante é representante de um determinado discurso social (MEINERZ, 2005).

No que se refere à operacionalização do grupo, as preocupações são praticamente as mesmas: o grupo deve ser composto de quatro a doze participantes, para que todos/as possam ter oportunidade de falar e ter, no máximo, duas horas de duração. O mediador/preceptor desempenha papel fundamental na introdução e estímulo ao debate; os participantes devem ser posicionados em círculo; depois de terminada a reunião, o pesquisador responsável, que é o provável mediador, deve fornecer lanche - e, no caso dos grupos focais com mais de um encontro, dar uma pequena lembrança para cada participante -; os custos com o transporte dos integrantes do grupo correm por conta da pesquisa, etc.

Espera-se que, nessa "fala em debate", produzam-se informações diferentes daquelas produzidas nas entrevistas, que é mais uma fala-resposta, construída numa interação mais confessional que pública, como é o caso dos grupos.

Também para os "grupos de debate" há uma "ficha de consentimento informado" que é preenchida pelo/a participante, autorizando o uso da sua fala na pesquisa, bem como reconhecendo que estava devidamente esclarecido quanto aos objetivos da sua participação no grupo (a ficha empregada na pesquisa pode ser encontrada no Anexo 2).

No caso da minha pesquisa, em particular, o grupo de debate foi empregado apenas com a cultura punk e se constituiu no último passo da pesquisa com esse grupo. Foi constituído após o contato com todos/as os membros durante o campo. Portanto, já conhecia todos/as e eles/as se conheciam entre si, o que faz com que a apropriação que fiz da metodologia tenha seguido caminhos pouco ortodoxos. No dia marcado, a chuva impediu a presença de alguns, mas o debate não foi prejudicado por isso. Tive cuidado em convidar pessoas que normalmente pouco dialogavam, nos momentos de encontro do grupo, como nos shows, de forma a poder confrontar as diferentes posições em torno dos mesmos referentes culturais. Ao todo, participaram do grupo cinco pessoas, dentre as quais apenas uma garota. O tema debatido girou basicamente em torno da cena punk atual da cidade, mas os próprios participantes conduziram a outras questões, que também foram relevantes e, depois, incorporadas à pesquisa, como a questão da identidade punk, do rótulo que se cola à pessoa e da autorotulação.

Inevitavelmente, estamos no campo dos processos de "instituição de identidade", de que fala Diógenes (1998), a partir de Bourdieu. Tem relação com a "imposição de um 
nome" que dá a quem o assume um "direito de ser que é também um dever ser". É preciso fazer ver, aos outros, o que se é, comportando-se de forma condizente com a identidade assumida.

A partir desse debate, ficou evidente quantas ambigüidades envolvem a cultura juvenil punk. Ao mesmo tempo em que permite experimentação - fora do que é normalmente disponibilizado ao jovem e à jovem -, há uma cobrança sobre aqueles que ficam "pulando de galho em galho". Por outro lado, há também uma pressão sobre aqueles que se definem isso ou aquilo, para ver até onde vai a sua convicção. É por isso que muitos evitam o rótulo, mesmo o mais genérico de punk, e acabam dizendo que estão na cena só por diversão. Ao invés do engajamento, preferem se situar numa posição de engajamento/desengajamento conjuntural.

Acredito que essa enxurrada de questões, que vêm junto com a adesão a uma cultura juvenil, que o/a jovem deve elaborar para si mesmo, revela a importância educativa dessa cultura: a elaboração de um argumento, de um discurso sobre si mesmo, que além de ser uma elaboração da auto-identidade, denota posicionamentos, que tendem a ser conscientemente assumidos, diante de uma série de questões do mundo socioespacial em que está inserido. Posicionamentos que devem ser constantemente reavaliados à luz do debate entre os pares, bem como na construção da própria trajetória biográfica do sujeito.

\section{SISTEMATIZAÇÃO E ESCRITA: O PROCESSO DE (RE)CONSTRUÇÃO TEÓRICA.}

Ao final da pesquisa empírica, a partir destas metodologias qualitativas, o pesquisador dispõe de uma grande variedade de informações, bastante ricas e muito pouco sistematizadas. O grande desafio é organizar o material num texto coerente, que tenha credibilidade científica e que, ao mesmo tempo, expresse, em uma linguagem clara, a dialogicidade (entre pesquisador, entrevistados/as e informantes em campo) que envolveu todo o processo.

Becker (1999) afirma que este é um desafio que aflige muitos pesquisadores que utilizam a observação participante - e eu diria mesmo que, aflige todos/as os/as pesquisadores/as que trabalham com metodologias qualitativas -, dada a impossibilidade de mensuração dos dados. 
No que se refere especificamente à observação participante, Becker (1999) lança a questão: como apresentar as conclusões da pesquisa e as evidências que conduziram à sua concretização? O próprio autor sugere que se faça uma descrição da "história natural de nossas conclusões", que consiste em apresentar

[...] as evidências tal como chegaram à atenção do observador durante os sucessivos estágios de conceitualização do problema. O termo "história natural" não implica a apresentação de cada um dos dados, mas somente das formas características que os dados assumiram em cada estágio da pesquisa. [...] Desse modo, a evidência é avaliada à medida que a análise substantiva é apresentada. Se este método for empregado, o leitor será capaz de acompanhar os detalhes e ver como e em que bases se chegou a qualquer das conclusões. Isso daria ao leitor [...] a oportunidade de fazer seu próprio julgamento quanto à adequação da prova e ao grau de confiança a ser atribuído à conclusão (BECKER, 1999, p. 64).

Também sobre a construção textual, Geertz (1978) argumenta que há uma distinção importante entre a cultura como "fato natural" e a cultura "entidade teórica", colocada nos textos de pesquisa. Para o autor, os textos que procuram descrever uma cultura são interpretações desta e não a cultura em si. Trata-se, portanto, de ficções, não no sentido de que são falsos esses textos, mas sim, que são construídos por um ato de imaginação do pesquisador, a partir de procedimentos pouco estruturados de pesquisa em que a subjetividade está ativamente envolvida.

Na produção final do texto, momento de interpretação e de (re)construção teórica, os comentários de Geertz têm implicações importantes e merecem ser considerados, pois indicam qual a dimensão que assume a teoria nesse processo.

Se a interpretação antropológica está construindo uma leitura do que acontece, então divorciá-la do que acontece - do que, nessa ocasião ou naquele lugar, pessoas específicas dizem, o que elas fazem, o que é feito a elas, a partir de todo o vasto negócio do mundo - é divorciá-la das suas implicações e torná-la vazia. Uma boa interpretação de qualquer coisa [...] leva-nos ao cerne do que nos propomos interpretar (GEERTZ, 1978, p. 28).

Ainda para este autor, a descrição etnográfica é, sobretudo, interpretativa e microscópica, o que não significa que a Antropologia não trabalhe em grande escala. Mas o antropólogo aborda as interpretações mais amplas, a partir de um conhecimento extensivo de assuntos muito pequenos.

O que é importante nos achados do antropólogo é sua especificidade complexa, sua circunstancialidade. É justamente com essa espécie de material produzido por um trabalho de campo quase obsessivo de peneiramento, a longo prazo, 
principalmente (embora não exclusivamente), qualitativo, altamente participante e realizado em contextos confinados, que os megaconceitos com os quais se aflige a ciência social contemporânea [...] podem adquirir toda a espécie de atualidade sensível que possibilita pensar não apenas realista e concretamente sobre eles, mas, o que é mais importante, criativa e imaginativamente com eles (GEERTZ, 1978, p. 33/34 - grifos meus).

O risco deste tipo de postura é a interpretação apresentar-se como auto-validante, como se ela devesse ser aceita por si mesma, pois é produto de uma pesquisa exaustiva de imersão num contexto específico, o que a distanciaria das possibilidades de julgamentos críticos. É claro que se assim fosse, não seria interessante do ponto de vista científico e esse é um grande dilema com o qual se depara a interpretação cultural construída a partir da observação participante. "Estamos reduzidos a insinuar teorias porque falta-nos o poder de expressá-las", disse Geertz (1978, p. 34).

A teorização possível deve manter-se o mais próxima possível do chão, não podendo alçar grandes vôos. Por isso, para este autor, o ensaio é a forma mais interessante de apresentar as conclusões nesse tipo de estudo. E, "qualquer generalidade que consegue alcançar surge da delicadeza de suas distinções, não da amplidão das suas abstrações" (GEERTZ, 1978, p. 35).

Nesse sentido, também desenvolve-se a argumentação de Peirano (1992). Mas a autora vai além, argumentando que a Antropologia Experimental, desenvolvida nos EUA, que articula a maneira como se faz a pesquisa de campo à forma como se escreve, tem uma preocupação central com a linguagem, com vistas a transpor a dimensão dialógica da pesquisa de campo para o texto. A proposta é mostrar a liberdade e transparência dos diálogos entre o pesquisador e o/a informante. Tal perspectiva abre espaço para criações e construções literárias, nas quais as fronteiras entre arte e ciência são ultrapassadas em nome de uma criação textual, que possa expressar os sentimentos e a vivência do pesquisador no campo.

E, nesse ponto, é preciso reconhecer, tal como o fez Winkin (1998, p. 143), que "[...] a capacidade ou incapacidade para a escritura pode modificar radicalmente a percepção da realidade do trabalho realizado." A escrita, assim, é algo fundamental, pois cabe a ela o poder de construir essa ponte entre o grupo estudado e o/a leitor/a, a quem se convida a participar do diálogo. Afinal, estamos no campo de uma concepção de pesquisa que não se sente na obrigação de produzir verdades, mas que busca construir um retrato sensível de um universo específico; que é capaz de encantar e emocionar, pesquisador e leitores/as e, assim, estimular e ampliar novas reflexões sobre o social, o 
cultural, o espacial, enfim, o humano e que podem e devem ser feitas no processo mesmo de leitura do trabalho.

$\mathrm{Na}$ pesquisa, procurando ser coerente com essas opções teórico-metodológicas, segui desenhando as trajetórias de vida das pessoas entrevistadas e conhecidas pela observação participante, articulando essas trajetórias, sobretudo das pessoas das gerações anteriores, com a trajetória histórica do próprio lugar e da juventude, em sentido mais amplo.

Assim, para narrar os processos de transformação dos tempos, espaços e práticas de sociabilidade, ao longo do tempo, tessi um texto em que fui apresentando pessoas, suas histórias de vida, suas vivências juvenis, conectando-as com a cidade e com as referências culturais, que, em cada momento, tinham à disposição como meio e condição para a vivência que realizavam.

O texto sobre cada uma das culturas juvenis também seguiu desenhando trajetórias. Iniciou-se com aquela das próprias culturas, do mundo ao lugar, e seguiu com trajetória da cultura no lugar, a partir da reconstituição da rede de sociabilidade em torno dela. As trajetórias de vida eram apresentadas nas suas articulações umas com as outras, de modo que cada pessoa ia se tornando familiar ao leitor, na medida em que sua história era desenrolada no texto.

Num segundo momento, desenhava um quadro mais contemporâneo de cada cultura, com as informações produzidas pela observação participante. Nesse momento, o relato seguiu o forma do diário de campo, traçando também uma trajetória, dessa vez da própria pesquisa, que se apresenta sem maquiagens. Buscava narrar os fatos como iam se sucedendo, pois revelavam o processo de chegada, entrada no grupo, convivência e desvendamento mútuo dos sujeitos (do pesquisador e dos informantes), chamando a atenção para o que os eventos me conduziram a pensar.

Ao final de cada parte do trabalho, procurava ascender a alguma abstração, para sair um pouco do chão da descrição densa, de modo a realizar uma interpretação, com tons de (re)construção teórica. Esse esforço não poderia deixar de ser feito, sob pena de parecer que o trabalho interpretativo seria deixado unicamente a cargo do/a leitor/a, mas a teorização que fecha cada parte do trabalho é, na verdade, o ponto de partida para um diálogo, sobre o que foi apresentado na descrição das trajetórias. Nas considerações finais, inclusive, há páginas em branco, no fim, para que o/a leitor/a já possa, ali mesmo, esboçar suas próprias conclusões. 
O texto, assim, foi intencionalmente construído como uma caixa de arquivo, feita para ser aberta e pesquisada. O/a leitor/a deve revirá-la com lápis e papel em mãos, para fazer suas anotações e buscar suas próprias conexões entre os fatos, eles próprios, resultados das contingências da pesquisa.

\section{ALGUMAS CONCLUSÕES DA PESQUISA.}

Algumas das conclusões, que as informações produzidas pelas metodologias analisadas permitiram chegar, apontam para uma reconstrução teórica que, na verdade, não negou as teorias em vigor, ao contrário, permitiram que elas fossem iluminadas com as cores do cotidiano, com os matizes da trama da vida humana se desenrolando no tempo e no espaço. Refiro-me aqui à teorias que procuram explicar o processo de integração regional à economia nacional, que tornaram a cidade de Guarapuava progressivamente mais articulada, a partir da década de 1950; à teoria que reconstrói a história da juventude no século XX, para a qual a juventude, como categoria social, foi se ampliando para todas as camadas sociais - visto que antes era restrita a estratos de maior poder aquisitivo -, ao mesmo tempo em que se pluralizava, numa série de manifestações culturais; à teoria da multiplicação dos contextos socioespaciais, que fala da fragmentação do espaço urbano, ao mesmo tempo que da sociedade urbana; à teoria da multiplicação dos territórios e de constituição dos territórios rede, como forma predominante de territorialização no mundo contemporâneo.

As práticas, espaços e tempos de sociabilidade juvenil da geração de 1950 giravam em torno da família e tinham a igreja como centro. As relações de trabalho sempre estavam também presentes, na medida em que amizades se formavam nesse espaço-tempo. Guarapuava, na época, era uma cidade de cerca de 5.000 habitantes, em que todas as pessoas se conheciam e se reconheciam nos passeios aos domingos, depois da missa.

A geração de 1970 encontrou outra cidade e outras referências culturais para realizar suas práticas e constituir seus espaços e tempos de sociabilidade. No começo da década, a cidade já contava com cerca de 40.000 habitantes e estava em rápida expansão, chegando ao final com quase 90.000 habitantes urbanos. Havia bairros novos que surgiam do dia para a noite, com uma população recém-chegada do campo e que forçava presença nos espaços e tempos de sociabilidade mais tradicionais da cidade. 
Espaços e tempos que já não giravam tanto em torno da família e da igreja, mas que eram mais marcada e especificamente juvenis, adentrando o sábado à noite, polarizado por uma lanchonete e por uma danceteria. O carro, numa cidade maior, era presença constante nessa sociabilidade e as pessoas já não mais se conheciam e reconheciam num espaço-tempo que Ihes era comum. A presença do rock produzia certas interferências e provocava distinções no cenário juvenil.

A geração atual, estudada por meio das culturas punk e hip-hop, já era bem mais plural, numa cidade que ultrapassava o número de 150.000 habitantes, que possuía múltiplos contextos de formação de grupos de sociabilidade e que estava conectada ao mundo por todas as novas tecnologias de comunicação existentes contemporaneamente. Não é por acaso que o punk chegou a Guarapuava e se difundiu, sobretudo, no ano 2000, quando já estavam postas na cidade a popularização da conexão de internet banda larga e da televisão por assinatura.

Para se ter uma ideia da multiplicação de contextos socioespaciais, a escola sempre foi importante espaço de agregação, nas diferentes gerações. Nas gerações de 1950 e 1970, o número das que apareceram nos relatos não ultrapassou o patamar de três. Já na geração do século XXI, o número das escolas que apareceram nas entrevistas superou uma quinzena.

Acompanhando a trajetória de aterrissagem no lugar das duas culturas juvenis transterritoriais, foi possível identificar, pelos depoimentos orais que, tanto o punk quanto o hip-hop não chegaram e se difundiram a partir de um único ponto. Diversos grupos juvenis, em contextos de escola e de bairros diferentes, descobriram as referências culturais globais e, só num segundo momento, foram se articulando entre si, formando uma rede de sociabilidade à escala da cidade como um todo, graças ao encontro desses grupos de bairro em alguns terminais de conexão no centro. O calçadão da cidade foi importante terminal de conexão para a cultura punk, enquanto a pista de skate do Parque do Lago (principal pista de skate da cidade) o foi para o hip-hop.

A observação participante, por sua vez, mostrou que, compartilhar a mesma cultura e fazer parte da mesma rede de sociabilidade não significa compartilhar as mesmas opiniões e a mesma vivência da cultura escolhida. Os conflitos, portanto, estão sempre presentes e interferem na força que a cultura tem, ou não, para se territorializar, mais efetivamente, no lugar.

Os territórios existentes são múltiplos, dizem respeito à escala do bairro e à escala da cidade, sendo este último formado por uma rede de redes de sociabilidade. O primeiro 
é mais permanente, visto que formado por relações mais estreitas de vizinhança e amizade. O segundo é mais efêmero, já que depende da dinâmica das culturas juvenis na própria cidade, mais dos contatos que das amizades estreitas. A pesquisa evidenciou que a proximidade física, no bairro, ainda joga papel importante na formação das redes de sociabilidade primárias, a partir das quais outras aproximações (ou distanciamentos) são produzidos nas (des)conexões à escala da cidade.

Enfim, muitas outras conclusões poderiam ser aqui tecidas, mas não é essa a intenção. O que vale ainda reforçar é que essas conclusões talvez não sejam válidas para as mesmas culturas juvenis estudadas em outros contextos urbanos, como em cidades de dimensão metropolitana, por exemplo, e, por isso, não se pretendem universais. Foram construídas num esforço de interpretação da particularidade densamente descrita e surgem daquilo que as evidência produzidas na pesquisa permitem dizer.

Com esta posição, imagino estar em sintonia com as opções metodológicas apresentadas e espero ter oferecido, neste artigo, alguns subsídios para que possamos, na Geografia, também ampliar o escopo da reflexão metodológica, como forma de produzirmos pesquisas mais refletidas e que busquem certa coerência interna entre teoria, metodologia, pesquisa de campo e produção textual.

\section{REFERÊNCIAS BIBLIOGRÁFICAS}

AMADO, J. O grande mentiroso: tradição, veracidade e imaginação em história oral. História, São Paulo, 14, p. 125-136, 1995.

BECKER, H. S. Métodos de pesquisa em ciências sociais. São Paulo: HUCITEC, 1999.

BOGDAN, R. O.; BIKLEN, S. K. Investigação qualitativa em educação: uma introdução à teoria e aos métodos. Porto: Editora Porto, 1994.

CICOUREL, A.. Teoria e método em pesquisa de campo. In: GUIMARÃES, A. Z. (org.). Desvendando máscaras sociais. Rio de Janeiro: Livraria Francisco Alves Editora, 1980. p. 87-121.

COHEN, Y. História oral: uma metodologia, um modo de pensar, um modo de transformar as ciências sociais? Ciências Sociais Hoje, São Paulo, no.??, p. 266 - 274, 1993.

CRUZ NETO, O.; MOREIRA, M. R.; SUCENA, L. F. M. Grupos focais e pesquisa social qualitativa: o debate orientado como técnica de investigação. In: Anais... Encontro da Associação Brasileira de Estudos Populacionais, XIII, Ouro Preto, 04 a 08 de novembro, de 2002 Disponível em www.abep.nepo.unicamp.br/docs/anais/pdf/2002/com JUV PO27 Neto textos.pdf, acessado em 06 de fevereiro de 2006. 
DA MATTA, R. O ofício de etnólogo, ou como ter anthropological blues. In: NUNES, E. de O. (org.). A aventura sociológica: objetividade, paixão, improviso e método na pesquisa social. Rio de janeiro: Zahar, 1978. p. 23-35.

DEBERT, G. G. Problemas relativos à utilização da história de vida e história oral. In: CARDOSO, R. C. L. (org.). A aventura antropológica: teoria e pesquisa. Rio de Janeiro: Paz e Terra, 1986. p. $141-156$.

DIÓGENES, G. Cartografias da cultura e da violência: gangues, galeras e movimento hip hop. São Paulo: Annablume; Fortaleza: Secretaria da Cultura e do Desporto, 1998.

FOOTE-WHYTE, W. Treinando a observação participante. In: GUIMARÃES, A. Z. (org.). Desvendando máscaras sociais. Rio de Janeiro: Livraria Francisco Alves Editora, 1980. p. 77-86.

GEERTZ, C. A interpretação das culturas. Rio de Janeiro: Zahar, 1978.

HAESBAERT, R. O mito da desterritorialização: do "fim dos territórios" à multiterritorialidade. Rio de Janeiro: Bertrand Brasil, 2004. 395 p.

HALL, M. M. História Oral: os riscos da inocência. In: PREFEITURA MUNICIPAL DE SÃO PAULO, Secretaria Municipal de Cultura, Departamento do Patrimônio Histórico. O direito à memória: patrimônio histórico e cidadania. São Paulo: DPH, 1992. 4 p.

IBÁÑEZ, J. Perspectivas de la investigación social: el diseño en las tres perspectivas. In: El análisis de la realidad social - métodos y técnicas de investigación. Madrid: Alianza Editorial, 1989. p. $49-83$.

LACERDA, E. P. Trabalho de campo e relativismo: a alteridade como crítica da antropologia. Disponível em www.antropologia.com, acessado em julho de 2003.

MACIOTI, M. I. Vida cotidiana. In: VON SIMON, O. de M. (org.). Experimentos com história de vida: Itália - Brasil. São Paulo: Vértice, Ed. Revista dos Tribunais, 1988. p. 177 $-192$.

MARCUS, G. Identidades passadas, presentes e emergentes: requisitos para etnografias sobre a modernidade no final do século XX ao nível mundial. Revista de Antropologia, São Paulo, n. 34, p. 197-221, 1991.

MARRE, J. A. L. A construção do objeto científico na investigação empírica. Cascavel: Seminário de Pesquisa do Oeste do Paraná - UNIOESTE, 1991. (Digitado)

MEIHY, José Carlos S. B. Manual de história oral. 4ª ed. São Paulo: Loyola, 2002. 246 p.

MEINERZ, Carla Beatriz. Adolescentes no pátio, outra maneira de viver a escola: um estudo sobre a sociabilidade a partir da inserção escolar na periferia urbana. Porto Alegre: UFRGS, 2005. - digitada. (Tese apresentada ao Programa de Pós-Graduação em Educação da Faculdade de Educação da Universidade Federal do Rio Grande do Sul), Porto Alegre, 2005.

ORTí, A. La apertura y el enfoque cualitativo o estructural: la entrevista abierta semidirectiva y la discusión de grupo. In: El análises de la realidad social - métodos y técnicas de investigación. Madrid: Alianza Editorial, 1989. p. 171 - 203. 
PEIRANO, M. G. S. Uma antropologia no plural: três experiências contemporâneas. Brasília: Ed. Universidade de Brasília, 1992.

QUEIROZ, M. I. P. de. Variações sobre a técnica de gravador no registro da informação viva. São Paulo: T. A. Queiróz, 1991. p. 1-26.

ROSA, G. de F. Corpos jovens como superfície de inscrição de textos culturais: recados para a educação escolar. Porto Alegre: UFRGS, digitado, 2004 (Dissertação apresentada ao Programa de Pós-Graduação em Educação da UFRGS).

SILVA, T. T. da. Documentos de identidade: uma introdução às teorias do currículo. Belo Horizonte: Autêntica, 2003.

THIOLLENT, M. J. M. Crítica metodológica, investigação social e enquete operária. São Paulo: Editora Polis, 1980. (Coleção Teoria e História 6).

TURRA NETO, N. Enterrado vivo: identidade punk e território em Londrina. São Paulo: Editora UNESP, 2004.

. Múltiplas trajetórias juvenis em Guarapuava: territórios e redes de sociabilidade. 2008. 516 f. Tese (Doutorado em Geografia) - Pós-Graduação em Geografia, Universidade Estadual Paulista. Presidente Prudente: 2008.

WINKIN, Y. Descer ao campo. In: campo. Campinas: Papirus, 1998. p. $129-145$.

A nova comunicação: da teoria ao trabalho de 


\section{ANEXO 1 \\ UNIVERSIDADE DO CENTRO-OESTE
CENTRO DE CIÊNCIAS AGRÁRIAS E AMBIENTAIS DEPARTAMENTO DE GEOGRAFIA}

\section{TERMO DE CONSENTIMENTO DE USO DA ENTREVISTA}

A Pesquisa Espaços e Tempos da Sociabilidade Juvenil em Guarapuava visa investigar as juventudes guarapuavanas quanto aos seus locais de encontro e diversão, suas referências culturais, suas músicas preferidas, para compreender como a juventude aconteceu e acontece em Guarapuava em cada período histórico - anos de 1950, 1970 e 2000. Para isso, pretende-se escutar pessoas de gerações diferentes que viveram sua juventude em Guarapuava, para captar as transformações que se processaram nas formas de ser jovem e nas formas de acontecer das juventudes guarapuavanas.

Os dados dos depoimentos estarão sob sigilo ético e não deverão ser divulgados até o momento de publicação da pesquisa, de modo que ela não oferece nenhum risco ao/a informante.

O pesquisador responsável pela pesquisa é o Professor do Departamento de Geografia da UNICENTRO, doutorando em Geografia pela UNESP de Presidente Prudente, que se compromete a esclarecer todas as dúvidas dos/as informantes, antes, durante e depois das entrevistas. Podendo ser contatado pelos telefones: ; ou ainda pelo correio eletrônico

$\mathrm{Eu}$,

$\begin{array}{llll}\text { portador/a do } & \text { documento } & \text { residente }\end{array}$

declaro para os devidos fins que cedo os direitos da minha entrevista para que seja transcrita, analisada e utilizada, no todo ou em partes, no âmbito da pesquisa acima citada. Da mesma forma, autorizo que seja usada posteriormente por terceiros vinculados à UNICENTRO, que ficará com a guarda do material após o término da pesquisa.

Também informo que ( ) permito a citação do meu nome na redação final da pesquisa ( ) não permito a citação do meu nome na redação final da pesquisa.

Guarapuava, de 20 


\section{ANEXO 2 \\ UNIVERSIDADE ESTADUAL DO CENTRO-OESTE /UNICENTRO DEPARTAMENTO DE GEOGRAFIA.}

\section{TERMO DE CONSENTIMENTO INFORMADO}

A pesquisa Espaços e Tempos da Sociabilidade Juvenil em Guarapuava: uma questão de identidade entre o lugar e o mundo, visa investigar alguns grupos culturais da cidade e as possibilidades que ela oferece para sua realização. Neste sentido, procura escutar os jovens em sua diversidade/pluralidade, em diferentes contextos sócio-culturais, com objetivo de ver o que os jovens pensam dos grupos que escolheram pertencer, da cidade e do seu cotidiano.

Os dados e resultados da pesquisa, especialmente os depoimentos dos jovens no grupo de discussão, estarão sempre sob sigilo ético, não sendo mencionados os nomes dos participantes em nenhuma apresentação oral ou trabalho que venha a ser publicado.

A participação na pesquisa não oferece risco ou prejuízo à pessoa participante. Se no decorrer da pesquisa o participante resolver cancelar o uso das informações prestadas, terá toda liberdade de o fazer, sem que isso lhe acarrete qualquer conseqüência.

O pesquisador responsável pela pesquisa é o Professor , do Departamento de Geografia da UNICENTRO, doutorando em Geografia pela UNESP de Presidente Prudente, que se compromete a esclarecer todas as dúvidas dos/as informantes, antes, durante e depois das entrevistas. Podendo ser contatado pelos telefones ; ou ainda pelo correio eletrônico

$\mathrm{Eu}$,

\begin{tabular}{llll}
\cline { 2 - 3 } portador/a do documento__residente & , declaro
\end{tabular}

para os devidos fins que cedo os direitos do meu depoimento para que seja transcrito, analisado e utilizado, no todo ou em partes, no âmbito da pesquisa acima citada. Da mesma forma, autorizo que seja usado posteriormente por terceiros vinculados à UNICENTRO, que ficará com a guarda do material após o término da pesquisa.

Fui informado/a das finalidades, objetivos e metodologias da investigação proposta na pesquisa. Dispus-me a participar da mesma, integrando um grupo de discussão, junto a outros jovens. Minhas dúvidas foram respondidas, no início da reunião do grupo e sei que poderei solicitar outros esclarecimentos. Além disso, sei que terei a liberdade de retirar meu consentimento de participação, a qualquer momento. Estou ciente de que as informações colhidas terão caráter confidencial e só serão divulgados dados gerais dos participantes da pesquisa, sem sua identificação.

Guarapuava, de de $20 \ldots$. 